Article

\title{
Chemical Synthesis of Marine-Derived Sulfoglycolipids, a New Class of Molecular Adjuvants
}

\author{
Emiliano Manzo ${ }^{1, *}$, Laura Fioretto ${ }^{1}$, Dario Pagano ${ }^{1}$, Genoveffa Nuzzo $^{1}$ (D), Carmela Gallo ${ }^{1}$ (D), \\ Raffaele De Palma ${ }^{2}$ and Angelo Fontana ${ }^{1}$ \\ 1 Bio-Organic Chemistry Unit, CNR-Institute of Biomolecular Chemistry, Via Campi Flegrei 34, \\ IT-80078 Pozzuoli, 80078 Napoli, Italy; laura_fioretto@hotmail.it (L.F.); dariopagano85@gmail.com (D.P.); \\ nuzzo.genoveffa@icb.cnr.it (G.N.); carmen.gallo@icb.cnr.it (C.G.); afontana@icb.cnr.it (A.F.) \\ 2 Department of Internal and Experimental Clinic, Clinical Immunology and Allergology, \\ University of Campania, c/o II Policlinico (Bd. 3), Via S.Pansini 5, 80131 Napoli, Italy; \\ Raffaele.DEPALMA@unicampania.it \\ * Correspondence: emanzo@icb.cnr.it; Tel.: +39-0818675310
}

Received: 27 July 2017; Accepted: 11 September 2017; Published: 20 September 2017

\begin{abstract}
Vaccines play a primary role in the protection of human health by preventing infectious and chronic diseases. Recently we have reported 1,2-O-distearoyl-3-O- $\beta$-D-sulfoquinovosylglycerol ( $\beta$-SQDG18), here named Sulfavant A (1), which shows promising properties as a new molecular adjuvant in in vitro and in vivo tests. In the present manuscript, we provide full details about a synthetic strategy for the preparation of $\mathbf{1}$, including a discussion of chemical determinants of the activity and the major technical hurdles we faced during the study. Synthesis of Sulfavant A (1) is achieved by a versatile procedure based on a trichloroacetimidate methodology and peracetate sugar precursors. The final design opens possibilities for the preparation of a series of interesting analogs for further pharmacological optimization and development, including derivatives containing different saturated and polyunsaturated fatty acids (e.g., 17 and 22).
\end{abstract}

Keywords: glycolipids; sulfolipid; vaccine; adjuvant; immunology; innate immunity; dendritic cells; immunogenic lipid; Sulfavant A

\section{Introduction}

Vaccination consists of the stimulation of immune response by vaccines, historically composed of attenuated or inactivated biological agents [1]. However, most recent vaccines are constituted by peptides or recombinant DNA, which are safer, but often insufficiently immunogenic [1]. To overcome this problem, modern vaccines contain adjuvants that are necessary to boost the immune response. To date, except for the monophosphoryl lipid A (MPLA), clinically approved formulations of adjuvants are restricted to aluminum salts and emulsions of lipids in water [2].

Dendritic cells (DCs) are the most important antigen-presenting cells (APCs), and play a pivotal role in starting immunogenic reactions and priming a long-lasting and antigen-specific response [3]. The ability to activate DCs is a key tool for improving the efficacy of vaccination [3].

Recently, in our ongoing research on immunomodulatory substances, we reported the pharmacological development of the non-natural 1,2-O-distearoyl-3-O- $\beta$-D-sulfoquinovosylglycerol, here named Sulfavant A (1) (Figure 1), as a prototype for a new class of molecular adjuvants based on a sulfolipid skeleton [4]. This family of products is structurally inspired by the natural $\alpha$-D-sulfoquinovosyl-diacylglycerols ( $\alpha$-SQDG), bioactive metabolites bearing a 6-sulfonic function on D-glucose (sulfoquinovose) linked to a glycerol moiety with two fatty acyl chains [5-20]. 
The natural sulfoglycoglycerolipids are marked by the $\alpha$-configuration of the anomeric carbon and the $\beta$-configuration type is not present in nature.

Sulfavant A (1) activates human DCs and triggers an efficient immune response in vivo [4]. After treatment, DCs show up-regulation of MHC II molecules and other co-stimulatory proteins (CD83, CD86), as well as production of pro-inflammatory cytokines (IL-12 and INF- $\gamma$ ). Mice immunized with OVA associated to Sulfavant A produced a release of anti-OVA Ig comparable to traditional adjuvants, while, in an experimental model of melanoma, vaccination of C57BL/ 6 mice with Sulfavant A-adjuvanted hgp10 peptide elicited a protective response leading to a promising reduction in tumor growth and increase of mice survival [4].

Here we discuss in detail the strategy for the synthesis of Sulfavant A (1), including an overview of the main technical hurdles we have faced, together with the considerations for the scale-up of the process and the possibility to expand the class of synthesizable analogs.

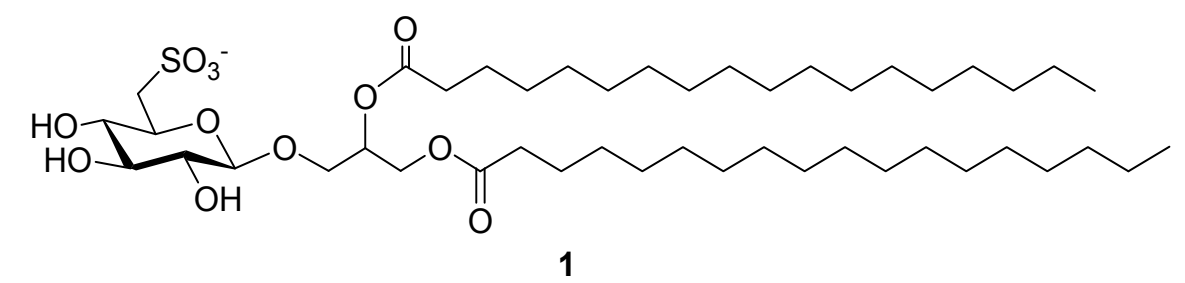

Figure 1. 1,2-O-distearoyl- $\beta-6^{\prime}$-sulfoquinovosylglycerol (Sulfavant A).

\section{Results and Discussion}

For the preparation of Sulfavant A, the main challenges lay in the requirement of planning a chemical strategy comprising the introduction of the $\beta$-glycosidic bond at the anomeric carbon and the insertion of the sulfonic function on $\mathrm{C}_{6}$ of glucose (Scheme 1). At the same time, the possibility of introducing different and unsaturated fatty acyl residues on the glycerol moiety would make the strategy expandable to a wide class of analogs. Furthermore, the process had to be suitable to scale-up for further pharmacological development.
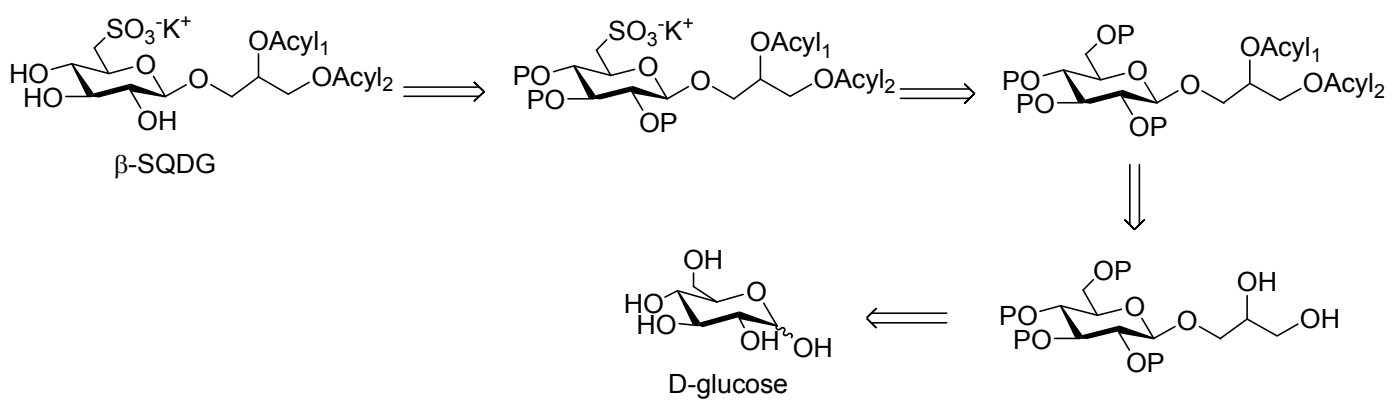

Scheme 1. Retrosynthetic scheme for preparation of Sulfavant A (1) and its analogs.

The first crucial point was the choice of orthogonal protecting groups on sugar, whose deprotection should not affect the diacylglycerol aglycon part and the glycosidic linkage. In this frame, tert-butyldimethylsilyl and benzyl groups to which the synthesis of $\alpha$ - and $\beta$-SQDGs $[14,21,22]$ had already been applied, were initially tested for the preparation of the sulfolipid. Unfortunately, the tert-butyldimethylsilyl group proved to be too labile in the experimental conditions and this, together with its low deprotection efficiency, led to a considerable decrease in yields; whereas the use of benzyl excluded the possibility of introducing unsaturated acyl chains to the glycerol, and greatly reduced the possibility of extending the synthesis to other analogs. For these reasons, we decided to explore the use of acetate as transient protecting group for the hydroxy functions of the sugar moiety. The acetoxy derivatives are stable under a wide range of conditions and, most importantly, the presence 
of the acetate residue at C-2' is capable of ensuring an excellent stereoselectivity in the formation of the $\beta$ glycosidic bond by anchimeric assistance $[23,24]$. On the other hand, acetate removal implies basic conditions that are not suitable for preserving the ester linkage of glycerol with the acyl chains. To this end, a careful tuning of hydrolysis by hydrazine was crucial to completing the synthesis of the sulfolipid [23,24].

As reported in Scheme 2, the total synthesis of Sulfavant A (1) started with acetylation of D-glucose, followed by selective deacetylation at the anomeric position with benzylamine and derivatization with trichloroacetimidate. The subsequent coupling with 1,2-O-isopropylidene glycerol by Schmidt methodology [25,26] gave the derivative 5 in high yields (about $80 \%$ ). As expected, the acetate groups determined the high stereoselectivity of the reaction $(\beta / \alpha$ ratio $95: 5)$ with the $\beta$-orientation of the glycosidic bond by neighboring group participation.
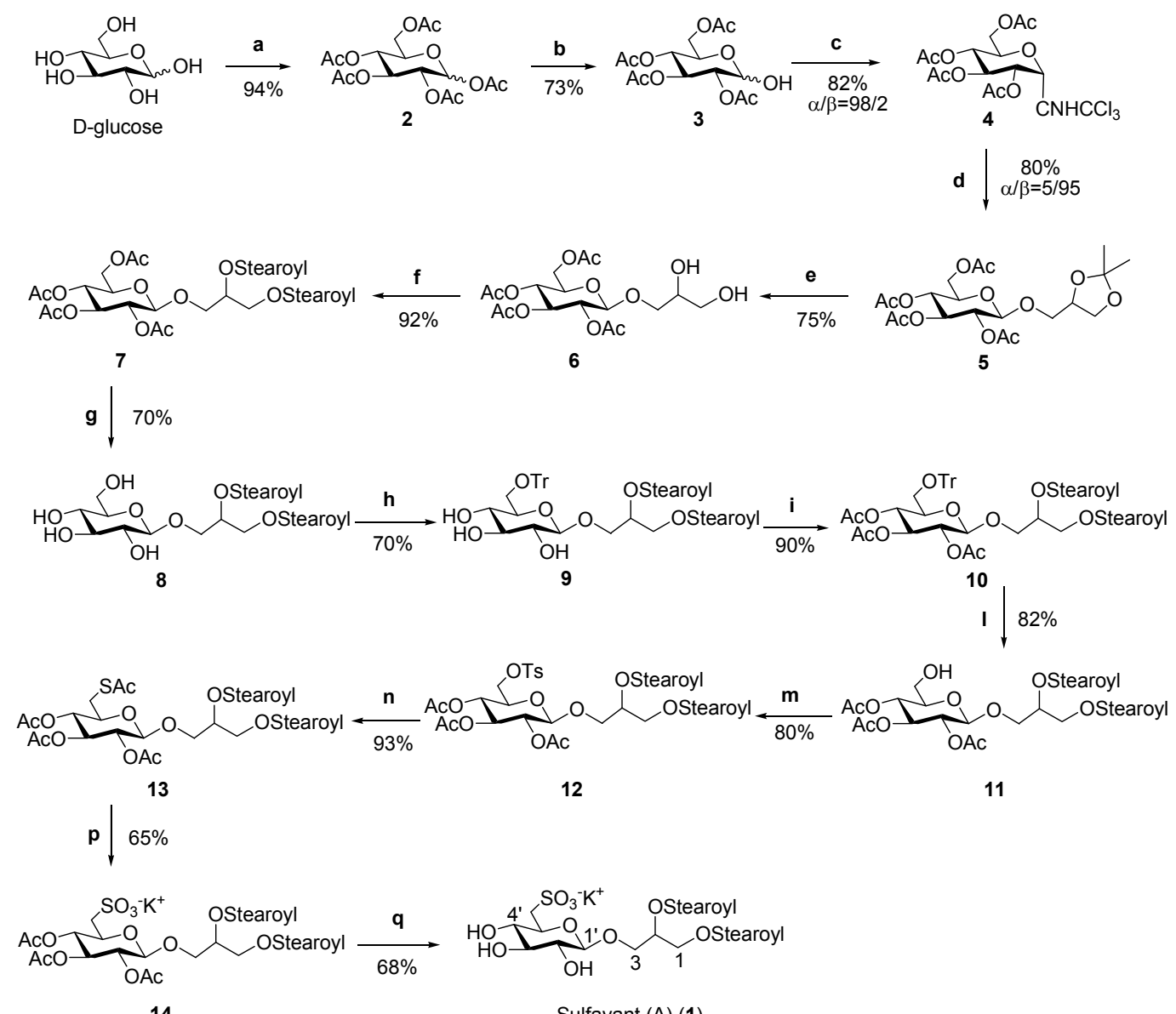

12

11

14

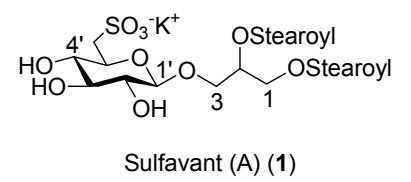

Scheme 2. (a) $\mathrm{Ac}_{2} \mathrm{O} /$ pyridine; (b) $\mathrm{BnNH}_{2}$, THF; (c) Trichloroacetonitrile, DBU, dichloromethane, $0{ }^{\circ} \mathrm{C}$; (d) $\mathrm{BF}_{3}-\mathrm{Et}_{2} \mathrm{O}$, glycerol acetonide, dichloromethane, molecular sieves $4 \mathrm{~A},-10{ }^{\circ} \mathrm{C}$; (e) $\mathrm{Zn}\left(\mathrm{NO}_{3}\right)_{6}-6 \mathrm{H}_{2} \mathrm{O}$, acetonitrile, $50{ }^{\circ} \mathrm{C}$; (f) Stearic acid, DCC, DMAP, dichloromethane; (g) hydrazine mono-hydrate, EtOH $85 \%, 45^{\circ} \mathrm{C}$; (h) $\mathrm{TrCl}$, pyridine; (i) $\mathrm{Ac}_{2} \mathrm{O} /$ pyridine; (l) $\mathrm{I}_{2}-\mathrm{MeOH}(1 \%), 60^{\circ} \mathrm{C}$; (m) Tosyl chloride, pyridine; (n) Potassium thioacetate, 2 butenone, $80^{\circ} \mathrm{C}$; (p) Hydrogen peroxide, acetic acid, potassium acetate, $40{ }^{\circ} \mathrm{C}$; (q) hydrazine mono-hydrate, $\mathrm{EtOH} 85 \%, 44^{\circ} \mathrm{C}$.

The next step was the removal of the isopropylidene residue under soft acidic conditions to preserve the glycosidic linkage. Use of zinc nitrate hexahydrate in acetonitrile allowed hydrolysis in quantitative yields [27], whereas $N, N$-dicyclohexylcarbodiimide (DCC)-mediated condensation with two equivalents of stearic acid yielded the diacyl derivative 7. At this point, with the aim of introducing the sulfonic function on carbon $6^{\prime}$, a selective removal of sugar acetyl groups without 
affecting the acyls on glycerol was necessary to obtain $\beta$-glucosyl-distearoyl-glycerol 8 . This was achieved by an accurate setting of the basic conditions that drove us to use monohydrate hydrazine in an amount of 2.4 moles per acetate unit at a temperature below $45^{\circ} \mathrm{C}$ [23,24]. After trytilation of the primary alcohol of glucose (compound 9, $70 \%$ ), acetylation (compound 10, 89\%), detrytilation [28] (compound 11, 82\%) and subsequent introduction on C-6 of the tosyl function (compound 12, 80\%) permitted the insertion of a thioacetate group (compound 13, 93\%) [29]. Final oxidation by hydrogen peroxide gave the corresponding sulfonic acid (compound 14,65\%), which was fully deacetylated by monohydrate hydrazine to give Sulfavant A (1) (68\%), whose NMR data are reported in Table 1.

Table 1. ${ }^{1} \mathrm{H}$ and ${ }^{13} \mathrm{C}$ NMR data of Sulfavant A (1) in $\mathrm{CDCl}_{3}: \mathrm{CD}_{3} \mathrm{OD}(1: 1), 400 \mathrm{MHz}$.

\begin{tabular}{ccc}
\hline Position & $\delta_{\mathbf{C}}$ & $\left.\delta_{\mathbf{H}}, \mathbf{m}, \boldsymbol{J} \mathbf{( H z}\right)$ \\
\hline $1^{\prime}$ & 103.4 & $4.34 / 4.32($ each for $1 \mathrm{H}), \mathrm{d}, 7.8$ \\
$2^{\prime}$ & 73.6 & $3.26, \mathrm{~m}$ \\
$3^{\prime}$ & 76.5 & $3.42, \mathrm{~m}$ \\
$4^{\prime}$ & 73.1 & $3.14, \mathrm{~m}$ \\
$5^{\prime}$ & 72.5 & $3.79-3.75, \mathrm{~m}$ \\
$6^{\prime} \mathrm{a}$ & 53.8 & $3.32, \mathrm{~m}$ \\
$6^{\prime} \mathrm{b}$ & 53.8 & $2.98, \mathrm{~m}$ \\
$1 \mathrm{a}$ & 63.3 & $4.47, \mathrm{~m}$ \\
$1 \mathrm{~b}$ & 63.3 & $4.19, \mathrm{~m}$ \\
2 & 70.5 & $5.29, \mathrm{~m}$ \\
$3 \mathrm{a}$ & 67.8 & $4.13-4.03, \mathrm{~m}$ \\
$3 \mathrm{~b}$ & 67.8 & $3.79-3.75, \mathrm{~m}$ \\
\hline Fatty acyls & & \\
\hline$\alpha-\mathrm{CH}_{\mathbf{2}}$ & 34.4 & $2.43-2.35$, overlapped \\
$\beta-\mathrm{CH}_{\mathbf{2}}$ & 25.1 & $1.69-1.54$, overlapped \\
$\mathrm{CH}_{\mathbf{2}}$ (chain) & $30.4-29.6$ & $1.32-1.25$, overlapped \\
$\mathrm{CH}_{\mathbf{3}}$ & 14.1 & 0.94, overlapped \\
\hline
\end{tabular}

Synthesis of Sulfavant A (1) was characterized by clean and efficient steps, along with a simple and easy workup, which makes the procedure suited for subsequent and crucial scaling-up. In fact, we did not face any problems in the transition from small to larger volumes. Furthermore, the workup did not require any particular experimental change in order to prepare hundreds of milligrams $(400 \mathrm{mg})$ of the product. On the basis of this process, we also expect that the synthetic procedure is able to provide grams of the vaccine adjuvant for in vivo tests and future pharmacological development.

The design of the synthetic strategy also opens possibilities for the preparation of a large range of analogs, including compounds with mixed composition of fatty acids or unsaturated acyl chains on glycerol moiety. An example of this is reported in Scheme 3 for the synthesis of 17, 1-O-stearoyl-2-O-palmitoyl-3-O- $\beta$-D-sulfoquinovosylglycerol, which contains two different fatty acids resgiospecifically distributed at the two positions of glycerol.

In this case, use of DCC at $4{ }^{\circ} \mathrm{C}$ permitted a good control of the step-wise introduction of two different acyl chains and gave yields of the monoacyl derivative $15(81 \%)$ significantly higher than those obtained by other methods [30-32]. Acylation of the primary hydroxy residue was largely favored in the first coupling reaction with equimolar amounts of fatty acid, and we did not observe any byproduct at C-2 of 15, as indicated by the NMR spectra, which showed deshielding of $\mathrm{H}_{2}-1$ signals at $\delta_{\mathrm{H}} 4.21-4.11$ (long range correlation of $\mathrm{H}_{2}-1$ to a carboxylic ester at $\delta_{\mathrm{C}} 171.1$ ) and $\delta_{\mathrm{H}}$ value of $\mathrm{H}-2$, linked to non-acylated oxygen, at $3.91 \mathrm{ppm}$ (Figure 2). 

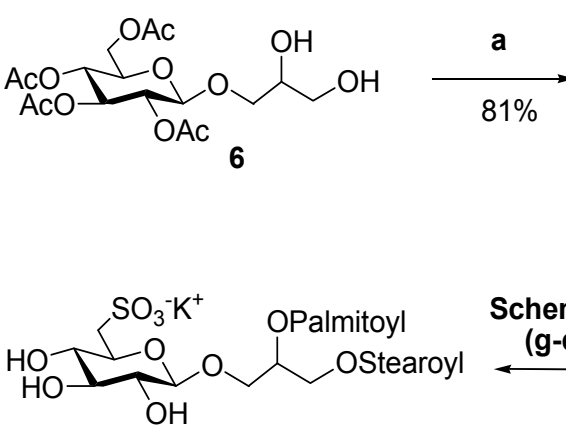

17

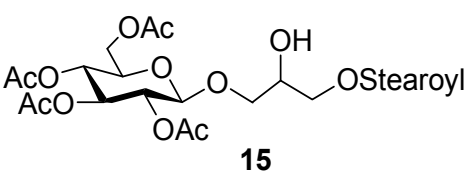

b $84 \%$
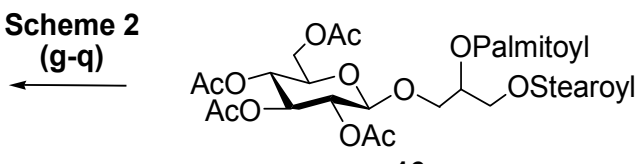

16

Scheme 3. (a) Stearic acid (1 equiv.), DCC, DMAP, dichloromethane, $4{ }^{\circ} \mathrm{C}$. (b) Palmitic acid (1,2 equiv.), DCC, DMAP, dichloromethane.

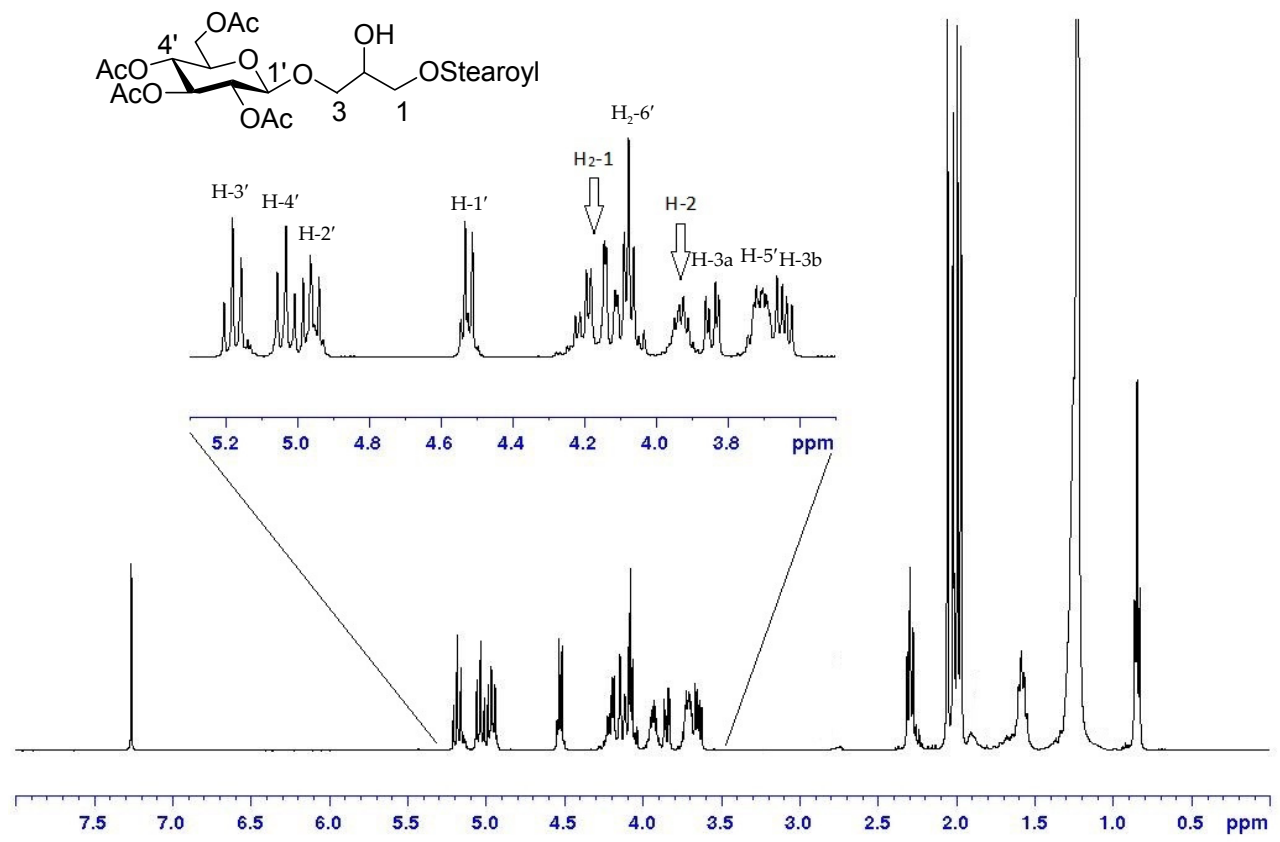

Figure 2. ${ }^{1} \mathrm{H}-\mathrm{NMR}$ of $15\left(\mathrm{CDCl}_{3}, 400 \mathrm{MHz}\right)$ and enlargement of the area between 5.3 and $3.5 \mathrm{ppm}$.

The introduction of acetate as protecting group also offers access to unsaturated analogs, as long as it is possible to control the sensitivity of double bonds to both the iodine and the hydrogen peroxide/acetic acid/acetate systems that are used for removal of the trityl group and sulfur oxidation, respectively. As shown in Scheme 4, this could be achieved by a slight modification of the synthetic procedure, and the use of an acidic resin to deprotect the primary hydroxy group and molybdate oxidation for the final step. Soft acidic conditions by Dowex $\mathrm{H}^{+}$at $50{ }^{\circ} \mathrm{C}$ in methanol/water $95 / 5$ allowed a complete removal of the trityl group while preserving the glycosidic bond of $\mathbf{1 9}$. The reaction led to formation of a small amount of other hydrolyzed byproducts, which were removed by chromatographic purification, but resulted in a slight decrease in the synthetic yield in comparison with the original step used for Sulfavant A. Molybdate oxidation has been used already for synthesis of $\alpha$-SQDGs [14], but application in the preparation of the $\beta$-SQDG required a careful adjustment of the reaction time. Increase in the temperature from room value to $50^{\circ} \mathrm{C}$, together with the use of twice the amount of ammonium heptamolybdate tetrahydrate and hydrogen peroxide, favoured the course of the reaction and led to the dioleoyl analog 22 with yield close to $60 \%$. 


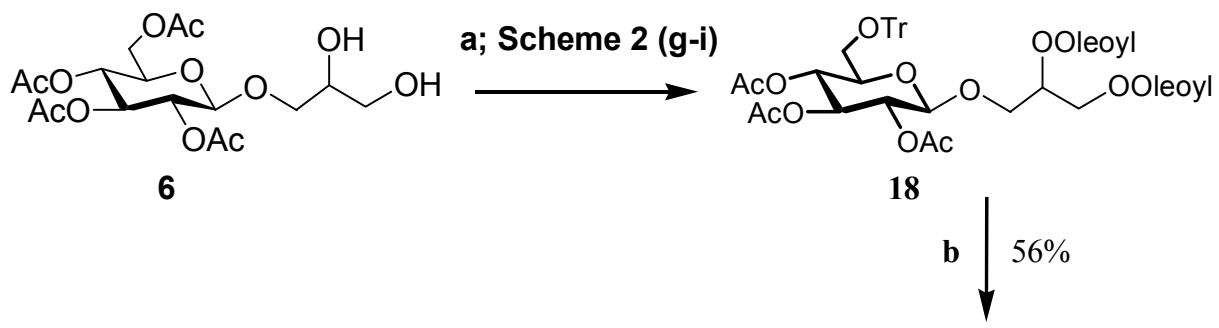

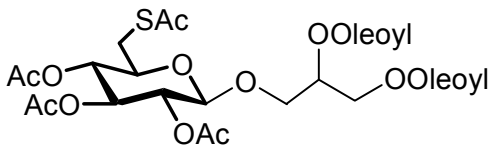

20

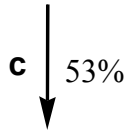

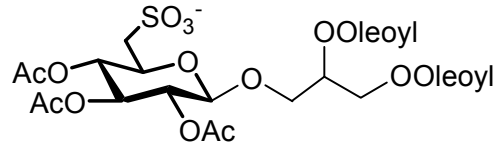

21
Scheme 2

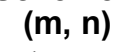

19
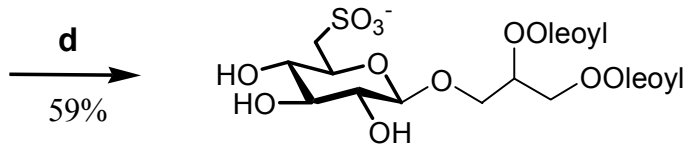

22

Scheme 4. (a) Oleic acid (2.3 equiv.), DCC, DMAP, dichloromethane; (b) Dowex- $\mathrm{H}^{+}, \mathrm{MeOH} / \mathrm{H}_{2} \mathrm{O}$ (95/5), $50{ }^{\circ} \mathrm{C}$; (c) $\left(\mathrm{NH}_{4}\right)_{6} \mathrm{Mo}_{7} \mathrm{O}_{24}-4 \mathrm{H}_{2} \mathrm{O}, \mathrm{H}_{2} \mathrm{O}_{2}, \mathrm{MeOH}, 50{ }^{\circ} \mathrm{C}$; (d) hydrazine mono-hydrate (2.4 equiv.), $\mathrm{EtOH} 85 \%$.

\section{Materials and Methods}

1D- and 2D-NMR spectra were recorded on a Bruker Avance-400 (400.13 MHz) and on a Bruker DRX-600 equipped with a TXI CryoProbe in $\mathrm{CDCl}_{3}$ and $\mathrm{CD}_{3} \mathrm{OD}\left(\delta\right.$ values are referred to $\mathrm{CHCl}_{3}$ and $\mathrm{CH}_{3} \mathrm{OH}$ at 7.26 and $3.34 \mathrm{ppm}$ respectively) and ${ }^{13} \mathrm{C}$ NMR spectra were recorded on a Bruker DPX-300 (75.47 MHz) ( $\delta$ values are referred to $\mathrm{CDCl}_{3}$ and $\mathrm{CD}_{3} \mathrm{OD}$ at 77.0 and $49.0 \mathrm{ppm}$ respectively). HRESIMS was conducted on a Micromass Q-TOF micro. TLC plates (Kieselgel $\left.60 \mathrm{~F}_{254}\right)$ and silica gel powder (Kieselgel 60, 0.063-0.200 mm) were from Merck.

All the reagents were purchased from Sigma-Aldrich and used without any further purification.

\section{Preparation and Characterization of Synthetic Molecules}

All the experimental procedures and spectral data of Sulfavant A (1) and synthetic intermediates 2-14 were reported in reference 4.

Compound 15: compound $6(0.148 \mathrm{~g}, 0.00035 \mathrm{~mol})$ was dissolved in anhydrous dichloromethane (5 mL); stearic acid $(0.0994 \mathrm{~g}, 0.00035 \mathrm{~mol})$, dicyclohexylcarbodiimide $(0.0721 \mathrm{~g}, 0.00035 \mathrm{~mol})$ and DMAP $(0.00427 \mathrm{~g}, 0.000035 \mathrm{~mol})$ were added at $0{ }^{\circ} \mathrm{C}$ and the reaction mixture was stirred overnight at $4{ }^{\circ} \mathrm{C}$; after evaporation under reduced pressure, the mixture was purified by silica gel chromatography using a gradient of petroleum ether/diethyl ether to give compound $15(0.165 \mathrm{~g}, 0.000284 \mathrm{~mol}, 81 \%)$. ${ }^{1} \mathrm{H}-\mathrm{NMR}(400 \mathrm{MHz}, \mathrm{CDCl} 3): \delta 5.18\left(1 \mathrm{H}, \mathrm{t}, J=9.6 \mathrm{~Hz}, \mathrm{H}-3^{\prime}\right), 5.04\left(1 \mathrm{H}, \mathrm{t}, J=9.6 \mathrm{~Hz}, \mathrm{H}-4^{\prime}\right), 4.97(1 \mathrm{H}$, $\left.\mathrm{dd}, J=8.1,9.6 \mathrm{~Hz}, \mathrm{H}-2^{\prime}\right), 4.53$ and 4.51 (each for $1 \mathrm{H}$ of the two epimers, $\left.\mathrm{d}, J=8.1 \mathrm{~Hz}, \mathrm{H}-1^{\prime}\right), 4.20(1 \mathrm{H}$, $\mathrm{dd}, J=5.2,12.0 \mathrm{~Hz}, \mathrm{H}-1 \mathrm{a}), 4.13(1 \mathrm{H}, \mathrm{dd}, J=2.4,12.0 \mathrm{~Hz}, \mathrm{H}-1 \mathrm{~b}), 4.09-4.06\left(2 \mathrm{H}, \mathrm{m}, \mathrm{H}_{2}-6^{\prime}\right), 3.91(1 \mathrm{H}$, m, H-2), $3.84(1 \mathrm{H}, \mathrm{dd}, 3.4,10.3 \mathrm{~Hz}, \mathrm{H}-3 \mathrm{a}), 3.70,\left(1 \mathrm{H}, \mathrm{m}, \mathrm{H}-5^{\prime}\right), 3.64(1 \mathrm{H}, \mathrm{dd}, 5.7,10.3 \mathrm{~Hz}, \mathrm{H}-3 \mathrm{~b}), 2.29$ $(2 \mathrm{H}, \mathrm{t}, J=7.1 \mathrm{~Hz}, \alpha$-methylene $), 2.07-1.96(12 \mathrm{H}, \mathrm{s}, 4 \mathrm{OAc}), 1.61-1.52$ ( $2 \mathrm{H}, \mathrm{m}, \beta$-methylene), $1.30-1.18$ (acyl chain methylenes), $0.84\left(3 \mathrm{H}, \mathrm{t}, 6.8 \mathrm{~Hz}, \mathrm{CH}_{3}\right)$; HRESIMS $m / z 711.3940[\mathrm{M}+\mathrm{Na}]+$ (calcd for $\mathrm{C}_{35} \mathrm{H}_{60} \mathrm{O}_{13} \mathrm{Na}$, 711.3932).

Compound 16: compound $15(0.165 \mathrm{~g}, 0.000284 \mathrm{~mol})$ was dissolved in anhydrous dichloromethane $(6 \mathrm{~mL})$; palmitic acid $(0.0738 \mathrm{~g}, 0.00034 \mathrm{~mol})$, dicyclohexylcarbodiimide $(0.07 \mathrm{~g}$, 
$0.00034 \mathrm{~mol})$ and DMAP $(0.0042 \mathrm{~g}, 0.000034 \mathrm{~mol})$ were added and the reaction mixture was stirred overnight; after evaporation under reduced pressure, the mixture was purified by silica gel chromatography using a gradient of petroleum ether/diethyl ether to give compound 16 (0.228 g, $0.00024 \mathrm{~mol}, 84 \%$ ); NMR data were identical to those of 7 [4]; HRESIMS $m / z 949.6235$ [M $+\mathrm{Na}^{+}$ (calcd for $\mathrm{C}_{51} \mathrm{H}_{90} \mathrm{O}_{14} \mathrm{Na}, 949.6228$ ).

Compound 17: NMR data were identical to those of Sulfavant A (1) (Table 1); HRESIMS $\mathrm{m} / \mathrm{z}$ $821.5454[\mathrm{M}-\mathrm{K}]^{-}$(calcd for $\left.\mathrm{C}_{43} \mathrm{H}_{81} \mathrm{O}_{12} \mathrm{~S}^{-}, 821.5454\right)$.

Compound 18: ${ }^{1} \mathrm{H}-\mathrm{NMR}\left(400 \mathrm{MHz}, \mathrm{CDCl}_{3}\right): \delta 7.47-7.18(15 \mathrm{H}, \mathrm{m}$, trityl portion), $5.36-5.32(4 \mathrm{H}$, m, olefinic protons), $5.23(1 \mathrm{H}, \mathrm{m}, \mathrm{H}-2), 5.15\left(1 \mathrm{H}, \mathrm{m}, \mathrm{H}-4^{\prime}\right), 5.14\left(1 \mathrm{H}, \mathrm{m}, \mathrm{H}-3^{\prime}\right), 5.05\left(1 \mathrm{H}, \mathrm{m}, \mathrm{H}-2^{\prime}\right), 4.54$ $\left(1 \mathrm{H}, \mathrm{d}, J=7.7 \mathrm{~Hz}, \mathrm{H}-1^{\prime}\right), 4.34(1 \mathrm{H}, \mathrm{dd}, J=4.1,12.0 \mathrm{~Hz}, \mathrm{H}-1 \mathrm{a}), 4.13(1 \mathrm{H}, \mathrm{dd}, J=5.9,12.0 \mathrm{~Hz}, \mathrm{H}-1 \mathrm{~b}), 4.03$ $(1 \mathrm{H}, \mathrm{dd}, J=4.9,11.1 \mathrm{~Hz}, \mathrm{H}-3 \mathrm{a}), 3.74(1 \mathrm{H}, \mathrm{dd}, J=5.1,11.1 \mathrm{~Hz}, \mathrm{H}-3 \mathrm{~b}), 3.55\left(1 \mathrm{H}, \mathrm{m}, \mathrm{H}-5^{\prime}\right), 3.27(1 \mathrm{H}, \mathrm{bd}$, $\left.J=10.2 \mathrm{~Hz}, \mathrm{H}-6^{\prime} \mathrm{a}\right), 3.09$ (1H, dd, $\left.J=2.3,10.2, \mathrm{H}-6^{\prime} \mathrm{b}\right), 2.31(2 \mathrm{H}, \mathrm{t}, J=7.5 \mathrm{~Hz}, \alpha$-methylene), $2.16(2 \mathrm{H}$, $\mathrm{t}, J=7.8 \mathrm{~Hz}, \alpha$-methylene), 2.10-2.01 (9H, s, 3 OAc), 2.03-2.00 (8H, overlapped, allylic protons), 1.54 ( $4 \mathrm{H}, \mathrm{m}, \beta$-methylene), 1.28-1.15 (acyl chain), $0.86\left(6 \mathrm{H}, \mathrm{t}, J=7.0 \mathrm{~Hz}, 2 \mathrm{CH}_{3}\right) ; \mathrm{HRESIMS} m / z 1173.7224$ $[\mathrm{M}+\mathrm{Na}]^{+}$(calcd for $\mathrm{C}_{70} \mathrm{H}_{102} \mathrm{O}_{13} \mathrm{Na}$, 1173.7218).

Compound 19: compound $18(0.1 \mathrm{~g}, 0.000087 \mathrm{~mol})$ was dissolved in methanol/water (95/5) solution and dowex- $\mathrm{H}^{+}(1.1 \mathrm{~g})$ was added and the reaction was stirred at $50{ }^{\circ} \mathrm{C}$ overnight; after filtration and evaporation under reduced pressure, the reaction mixture was purified by silica gel chromatography using a gradient of petroleum ether/diethyl ether to give compound 19 (0.044 g, $0.000048,56 \%) ; \delta 5.37-5.33$ (4H, m, olefinic protons), 5.31-5.28 (2H, overlapped, $\left.\mathrm{H}-2, \mathrm{H}-3^{\prime}\right), 5.08-5.00$ $\left(2 \mathrm{H}, \mathrm{m}, \mathrm{H}-2^{\prime}, \mathrm{H}-4^{\prime}\right), 4.61\left(1 \mathrm{H}, \mathrm{d}, J=7.8 \mathrm{~Hz}, \mathrm{H}-1^{\prime}\right), 4.36(1 \mathrm{H}, \mathrm{m}, \mathrm{H}-1 \mathrm{a}), 4.16(1 \mathrm{H}, \mathrm{m}, \mathrm{H}-1 \mathrm{~b}), 3.92(1 \mathrm{H}, \mathrm{m}$, H-3a), 3.78 (1H, m, H-3b), $3.74\left(1 \mathrm{H}, \mathrm{m}, \mathrm{H}-6^{\prime} \mathrm{a}\right), 3.60\left(1 \mathrm{H}, \mathrm{m}, \mathrm{H}-6^{\prime} \mathrm{b}\right), 3.54\left(1 \mathrm{H}, \mathrm{m}, \mathrm{H}-5^{\prime}\right), 2.41-2.29(4 \mathrm{H}, \mathrm{m}$, $\alpha$-methylene), 2.10-2.01 (9H, s, 3 OAc), 2.04-2.01 (8H, overlapped, allylic protons), 1.62-1.52 (4H, m, $\beta$-methylene), 1.33-1.15 (acyl chain), $0.90\left(6 \mathrm{H}, \mathrm{t}, J=7.0 \mathrm{~Hz}, 2 \mathrm{CH}_{3}\right)$; HRESIMS $m / z 931.6118$ [M + Na] (calcd for $\mathrm{C}_{51} \mathrm{H}_{88} \mathrm{O}_{13} \mathrm{Na}$, 931.6123).

Compound 20: ${ }^{1} \mathrm{H}-\mathrm{NMR}\left(400 \mathrm{MHz}, \mathrm{CDCl}_{3}\right): \delta 5.35-5.31$ (4H, m, olefinic protons), $5.18-5.14(2 \mathrm{H}$, m, H-2, H-3'), 4.96-4.89 (2H, m, H-2' $\left.{ }^{\prime} \mathrm{H}^{\prime} 4^{\prime}\right), 4.50\left(1 \mathrm{H}, \mathrm{d}, J=8.0 \mathrm{~Hz}, \mathrm{H}-1^{\prime}\right), 4.28(1 \mathrm{H}, \mathrm{dd}, J=4.1,11.8 \mathrm{~Hz}$, $\mathrm{H}-1 \mathrm{a}), 4.08(1 \mathrm{H}, \mathrm{dd}, J=5.7,11.8 \mathrm{~Hz}, \mathrm{H}-1 \mathrm{~b}), 3.91(1 \mathrm{H}, \mathrm{dd}, J=4.5,11.1 \mathrm{~Hz}, \mathrm{H}-3 \mathrm{a}), 3.65(1 \mathrm{H}, \mathrm{dd}, J=5.4$, $11.1 \mathrm{~Hz}, \mathrm{H}-3 \mathrm{~b}), 3.62\left(1 \mathrm{H}, \mathrm{m}, \mathrm{H}-5^{\prime}\right), 3.24\left(1 \mathrm{H}, \mathrm{bd}, J=11.4 \mathrm{~Hz}, \mathrm{H}-6^{\prime} \mathrm{a}\right), 3.05(1 \mathrm{H}, \mathrm{dd}, J=2.4 \mathrm{~Hz}, 11.4 \mathrm{~Hz})$, 2.33-2.29 (4H, m, $\alpha$-methylene), 2.13-1.98 (9H, s, $3 \mathrm{OAc}), 2.05-2.01$ (8H, overlapped, allylic protons), 1.64-1.57 (4H, m, $\beta$-methylene), 1.32-1.23 (acyl chain), 0.91-0.87 (6H, overlapped, $\left.2 \mathrm{CH}_{3}\right)$; HRESIMS $\mathrm{m} / \mathrm{z} 989.6007[\mathrm{M}+\mathrm{Na}]^{+}$(calcd for $\mathrm{C}_{53} \mathrm{H}_{90} \mathrm{O}_{13} \mathrm{NaS}$, 989.6000).

Compound 21: to a solution of compound $20(0.04 \mathrm{~g}, 0.000041 \mathrm{~mol})$ in methanol $(8 \mathrm{~mL})$ ammonium heptamolybdate tetrahydrate $\left[\left(\mathrm{NH}_{4}\right)_{6} \mathrm{Mo}_{7} \mathrm{O}_{24} 4 \mathrm{H}_{2} \mathrm{O}\right](0.051 \mathrm{~g}$, 1 equiv., $0.000041 \mathrm{~mol})$ in $30 \% \mathrm{H}_{2} \mathrm{O}_{2}$ $(1.0 \mathrm{~mL})$ was added with stirring. After $24 \mathrm{~h}$ at $50{ }^{\circ} \mathrm{C}$ the mixture was diluted with water and extracted with ethylacetate; the organic phase was purified by silica gel chromatography using a gradient of chloroform/methanol to give $21(0.022 \mathrm{~g}, 0.000022 \mathrm{~mol}, 53 \%) ; \delta 5.36-5.31(4 \mathrm{H}$, m, olefinic protons), $5.27(1 \mathrm{H}, \mathrm{m}, \mathrm{H}-2), 5.18(1 \mathrm{H}, \mathrm{dd}, 8.9,8.9 \mathrm{~Hz}, \mathrm{H}-3), 5.08-4.99\left(2 \mathrm{H}, \mathrm{m}, \mathrm{H}-2^{\prime}, \mathrm{H}-4^{\prime}\right), 4.68(1 \mathrm{H}, \mathrm{d}, 7.3 \mathrm{~Hz}$, H-1'), $4.31(1 \mathrm{H}, \mathrm{dd}, J=5.1,11.1 \mathrm{~Hz}, \mathrm{H}-1 \mathrm{a}), 4.15-4.06$ (3H, overlapped, H-1b, H-3a, H-5'), $3.75(1 \mathrm{H}, \mathrm{m}$, $\mathrm{H}-3 \mathrm{~b}), 3.20$ (2H, overlapped, $\left.\mathrm{H}_{2}-6^{\prime}\right), 2.33-2.28$ ( $4 \mathrm{H}, \mathrm{m}, \alpha$-methylene), 2.06-1.98 (9H, s, $\left.3 \mathrm{OAc}\right), 2.05-2.00$ ( $8 \mathrm{H}$, overlapped, allylic protons), $1.64-1.55$ ( $4 \mathrm{H}, \mathrm{m}, \beta$-methylene), $1.34-1.22$ (acyl chain), $0.91-0.88$ (6H, overlapped, $2 \mathrm{CH}_{3}$ ); HRESIMS $m / z 971.5764[\mathrm{M}-\mathrm{K}]^{-}$(calcd for $\mathrm{C}_{51} \mathrm{H}_{87} \mathrm{O}_{15} \mathrm{~S}^{-}$, 971.5771).

Compound 22: compound 21 (0.022 g, $0.000022 \mathrm{~mol})$ was dissolved in aq. ethanol (85\%) (4 mL), hydrazine monohydrate $(0.00016 \mathrm{~mol}, 2.4$ equiv. $)$ was added, and the reaction mixture was stirred for $6 \mathrm{~h}$ at $44^{\circ} \mathrm{C}$. After evaporation under a stream of nitrogen, the mixture was purified by silica gel chromatography using a gradient of chloroform/methanol to obtain $22(0.011 \mathrm{~g}, 0.000013 \mathrm{~mol}, 59 \%)$ ${ }^{1} \mathrm{H}-\mathrm{NMR}$ (400 MHz, $\left.\mathrm{CDCl}_{3} / \mathrm{CD}_{3} \mathrm{OD} 1 / 1\right)$ : $\delta 5.34-5.27$ (5H, overlapped, $\mathrm{H}-2$ and olefinic protons), 4.47 $(1 \mathrm{H}, \mathrm{m}, \mathrm{H}-1 \mathrm{a}), 4.34$ and 4.32 (each for $\left.1 \mathrm{H}, \mathrm{d}, 7.8 \mathrm{~Hz}, \mathrm{H}^{\prime} \mathrm{1}^{\prime}\right), 4.19$ (1H, m, H-1b), 4.13-4.03 (1H, m, H-1a), 3.79-3.75 (2H, m, H-3b, H-5'), $3.42\left(1 \mathrm{H}, \mathrm{m}, \mathrm{H}-3^{\prime}\right), 3.32\left(1 \mathrm{H}, \mathrm{m}, \mathrm{H}-6^{\prime} \mathrm{a}\right), 3.26\left(1 \mathrm{H}, \mathrm{m}, \mathrm{H}-2^{\prime}\right), 3.14(1 \mathrm{H}, \mathrm{m}$, $\left.\mathrm{H}-4^{\prime}\right), 2.98$ (1H, m, H-6 $\left.{ }^{\prime} \mathrm{b}\right), 2.43-2.35$ (4H, m, $\alpha$-methylene), 2.06-2.01 (8H, m, allylic protons), 1.69-1.58 
(4H, $\mathrm{m}, \beta$-methylene), 1.43-1.29 (acyl chain), 0.94 (6H, overlapped, $\left.2 \mathrm{CH}_{3}\right) ; \mathrm{HRESIMS} m / z$ 845.5460 $[\mathrm{M}-\mathrm{K}]^{-}$(calcd for $\mathrm{C}_{45} \mathrm{H}_{81} \mathrm{O}_{12} \mathrm{~S}^{-}$, 845.5454).

\section{Conclusions}

Sulfavant A (1) is a synthetic $\beta$-sulfoglycolipid with promising potential for immunomodulant and adjuvant activity. Synthesis of this molecule was achieved by a versatile and simple chemical procedure involving stereoselective glycosylation of trichloroacetimidate-glucose donor with 1,2-O-isopropylidene glycerol acceptor. In addition to the simplification of the synthetic steps, the trichloroacetimidate methodology and the use of acetate as the main protecting group of the sugar donor permit the synthesis in high yields of saturated and unsaturated $\beta$-anomer SQDG derivatives with mixed composition of fatty acids (e.g., 17 and 22). The proposed procedure has versatile applications, and allows access to a wide family of regio-pure compounds. The efficiency and simplicity of the strategy also allow a scale-up of the synthetic approach, leading to amounts of pure $\beta$-SQDGs for in vivo tests and future pharmacological development.

Supplementary Materials: The following are available online at http:/ /www.mdpi.com/1660-3397/15/9/288/s1, Figure S1: COSY and HMBC spectra of 15.

Acknowledgments: This work was funded by the Italian National Research Council. The authors acknowledge the contribution of the MIUR (Italian Research Ministry of Research) project "Antigens and adjuvants for vaccines and immunotherapy" (PON01_00117). The authors thank D. Melck of ICB-NMR service.

Author Contributions: E.M., L.F. and D.P. designed and carried out the chemical synthesis of sulfoquinovosides; G.N. and C.G. purified the synthetic molecules; E.M. and A.F. provided intellectual input and assisted with experimental design and writing of the paper; E.M., A.F. and R.D.P. conceived the study and analyzed the results together.

Conflicts of Interest: The authors declare no competing financial interest.

\section{References}

1. Di Pasquale, A.; Preiss, S.; Da Silva, F.T.; Garcon, N. Vaccine Adjuvants: Form 1920 to 2015 and Beyond. Vaccines 2015, 3, 320-343. [CrossRef] [PubMed]

2. Rappuoli, R.; Mandl, C.W.; Black, S.; De Gregorio, E. Vaccines for the twenthy-first century society. Nat. Rev. Immunol. 2011, 11, 865-872. [PubMed]

3. Kastenmuller, W.; Kastenmuller, K.; Kurts, C.; Seder, R.A. Dendritic cell-targeted vaccines-hope or hype? Nat. Rev. Immunol. 2014, 14, 705-711. [CrossRef] [PubMed]

4. Manzo, E.; Cutignano, A.; Pagano, D.; Gallo, C.; Barra, G.; Nuzzo, G.; Sansone, C.; Ianora, A.; Urbanek, K.; Fenoglio, D.; et al. A new marine-derived sulfoglycolipid triggers dendritic cell activation and immune adjuvant response. Sci. Rep. Nat. 2017, in press. [CrossRef] [PubMed]

5. Sahara, H.; Ishikawa, M.; Takahashi, N.; Ohtani, S.; Sato, N.; Gasa, S.; Akino, T.; Kikuchi, K. In vivo anti-tumour effectof $3^{\prime}$-sulphonoquinovosyl $1^{\prime}$-monoacylglyceride isolated from sea urchin (Strongylocentrotus intermedius) intestine. Br. J. Cancer 1997, 75, 324-332. [CrossRef] [PubMed]

6. Golik, J.; Dickey, J.K.; Todderud, G.; Lee, D.; Alford, J.; Huang, S.; Klohr, S.; Eustice, D.; Aruffo, A.; Agler, M.L. Isolation and Structure Determination of Sulfonoquinovoyl Dipalmitoyl Glyceride, a P-selectin Receptor Inhibitor from the Alga Dictyochloris fragrans. J. Nat. Prod. 1997, 60, 387-389. [CrossRef] [PubMed]

7. Loya, S.; Reshef, V.; Mizrachi, E.; Silberstein, C.; Rachamim, Y.; Carmeli, S.; Hizi, A. The Inhibition of the Reverse Transcriptase of HIV-1 by the Natural Sulfoglycolipids from Cyanobacteria: Contribution of Different Moieties to Their High Potency. J. Nat. Prod. 1998, 61, 891-895. [CrossRef] [PubMed]

8. Gustafson, R.; Cardelina, J.H.; Fuller, R.W.; Weislow, O.S.; Kiser, R.F.; Snader, K.M.; Patterson, G.M.L.; Boyd, M.R. AIDS-Antiviral Sulfolipids From Cyanobacteria (Blue-Green Algae). J. Nat. Cancer Inst. 1989, 81, 1254-1258. [CrossRef] [PubMed]

9. Murakami, C.; Yamazaki, T.; Hanashima, S.; Takahashi, S.; Ohta, K.; Yoshida, H.; Sugawara, F.; Sakaguchi, K.; Mizushina, Y. Structure-function relationship of synthetic sulfoquinovosyl-acylglycerols as mammalian DNA polymerase inhibitors. Arch. Biochem. Biophys. 2002, 403, 229-236. [CrossRef] 
10. Matsumoto, Y.; Sahara, H.; Fujita, T.; Shimozawa, K.; Takenouchi, M.; Torigoe, T.; Hanashima, S.; Yamazaki, T.; Takahashi, S.; Sugawara, F.; et al. An immunosuppressive effect by synthetic sulfonolipids deduced from sulfoquinovosyl diacylglycerols of sea urchin. Transplantation 2002, 74, 261-267. [CrossRef] [PubMed]

11. Matsumoto, Y.; Sahara, H.; Fujita, T.; Hanashima, S.; Yamazaki, T.; Takahashi, S.; Sugawara, F.; Mizushina, Y.; Ohta, K.; Takahashi, N.; et al. A novel immunosuppressive agent, SQDG, derived from sea urchin. Transplant. Proc. 2000, 32, 2051-2053. [CrossRef]

12. Ohta, K.; Mizushina, Y.; Yamazaki, T.; Hanashina, S.; Sugawara, F.; Sakaguchi, K. Specific interaction between an Oligosaccharide on the Tumour Cell Surface and the Novel Antitumour Agents, Sulfoquinovosylacylglycerols. Biochem. Biophys. Res. Commun. 2001, 288, 893-900. [CrossRef] [PubMed]

13. Reshef, V.; Mizrachi, E.; Maretzki, T.; Silberstein, C.; Loya, S.; Hizi, A.; Carmeli, S. New Acylated Sulfoglycolipids and Digalactolipids and Related Known Glycolipids from Cyanobacteria with a Potential to Inhibit the Reverse Transcriptase of HIV-1. J. Nat. Prod. 1997, 60, 1251-1260. [CrossRef] [PubMed]

14. Hanashima, S.; Mizushina, Y.; Yamazaki, T.; Ohta, K.; Takahashi, S.; Sahara, H.; Sagakuchi, K.; Sugawara, F. Synthesis of sulfoquinovosylacylglycerols, inhibitors of Eukaryotic DNA Polymerase $\alpha$ and $\beta$. Bioorg. Med. Chem. 2001, 9, 367-376. [CrossRef]

15. Hanashima, S.; Mizushina, Y.; Yamazaki, T.; Ohta, K.; Takahashi, S.; Koshino, H.; Sahara, H.; Sagakuchi, K.; Sugawara, F. Structural determination of sulfoquinovosyldiacylglycerol by chiral syntheses. Tetrahedron Lett. 2000, 41, 4403-4407. [CrossRef]

16. Mizushina, Y.; Maeda, N.; Kawasaki, M.; Ichikawa, H.; Murakami, C.; Takemura, M.; Xu, X.; Sugawara, F.; Fukumori, Y.; Yoshida, H.; Sakaguchi, K. Inhibitory action of emulsified sulfoquinovosyl acylglycerol on mammalian DNA polymerases. Lipids 2003, 38, 1065-1074. [CrossRef] [PubMed]

17. Hanashima, S.; Mizushina, Y.; Ohta, K.; Yamazaki, T.; Sugawara, F.; Sakaguchi, K. Structure-Activity Relationship of a ovel Group of Mammalian DNA Polymerase Inhibitors, Synthetic Sulfoquinovosylacylglycerols. Jpn. J. Cancer Res. 2000, 91, 1073-1083. [CrossRef] [PubMed]

18. Mizushina, Y.; Watanabe, I.; Ohta, K.; Takemura, M.; Sahara, H.; Takahashi, N.; Gasa, S.; Sugawara, F.; Matsukage, A.; Yoshida, S.; et al. Studies on inhibitors of mammalian DNA polymerase $\alpha$ and $\beta$ : Sulfolipids from a pteridophyte, Athyrium niponicum. Biochem. Pharmacol. 1998, 55, 537-541. [CrossRef]

19. Ohta, K.; Hanashima, S.; Mizushina, Y.; Yamazaki, T.; Saneyoshi, M.; Sugawara, F.; Sakaguchi, K. Studies on a novel DNA polymerase inhibitor group, synthetic sulfoquinovosylacylglycerol: inhibitory action on cell proliferation. Mutat. Res. 2000, 467, 139-152. [CrossRef]

20. Mizushina, Y.; Xu, X.; Asahara, H.; Takemura, M.; Yamaguchi, T.; Kuroda, K.; Linn, S.; Yoshida, H.; Koiwai, O.; Saneyoshi, M.; et al. A sulfoquinovosyl diacylglycerol is a DNA polymerase epsilon inhibotor. Biochem. J. 2003, 370, 299-305. [CrossRef] [PubMed]

21. Gigg, R.; Penglis, A.A.E.; Conant, R. Synthesis of 3-O-(6-deoxy-6-sulfo- $\alpha$-D-glucopyranosyl)-1,2-di-Ohexadecanoyl-L-glycerol, 'sulphoquinovosyl diglyceride'. J. Chem. Soc. 1980, 2490-2493.

22. Yamazaki, T.; Aoki, S.; Ohta, K.; Hyuma, S.; Sakaguchi, K.; Sugawara, F. Synthesis of an immunosuppressant SQAG9 and the determination of the binding peptide by T7 phage display. Bioorg. Med. Chem. Lett. 2004, 4343-4346. [CrossRef] [PubMed]

23. Manzo, E.; Ciavatta, M.L.; Pagano, D.; Fontana, A. An efficient and verstaile chemical synthesis of bioactive glyco-glycerolipids. Tetrahedron Lett. 2012, 53, 879-881. [CrossRef]

24. Pagano, D.; Cutignano, A.; Manzo, E.; Tinto, F.; Fontana, A. Glycolipids synthesis: Improved hydrazinolysis conditions for preparation of 1,2-polyunsaturated fatty acyl- $\beta$-monogalactosyl-glycerols. Carbohydr. Res. 2016, 424, 21-23. [CrossRef] [PubMed]

25. Schmidt, R.R.; Michel, J. Facile synthesis of $\alpha$ - and $\beta$-O-Glycosil Imidates; Preparation of Glycosides and Disaccharides. Angew. Chem. Int. Ed. Engl. 1980, 19, 731-732. [CrossRef]

26. Schmidt, R.R. New Methods for the Synthesis of Glycosides and Oligosaccharides-Are There Alternatives to the Koenigs-Knorr Method? [New Synthetic Methods (56)]. Angew. Chem. Int. Ed. 1986, 25, $212-235$. [CrossRef]

27. Vijayasaradhi, S.; Singh, J.; Aidhen, I.S. An Efficient, Selective Hydrolysis of Terminal Isopropylidene Acetal Protection by $\mathrm{Zn}\left(\mathrm{NO}_{3}\right)_{2} 6 \mathrm{H}_{2} \mathrm{O}$ in Acetonitrile. Synlett 2000, 110-112.

28. Wahlstrom, J.L.; Ronald, R.C. Detritylation of Ethers using Iodine-Alcohol Reagents: An Acid Catalytized Reaction. J. Org. Chem. 1998, 63, 6021-6022. [CrossRef] [PubMed] 
29. Fernandez-Bolanos, J.G.; Morales, J.; Garcia, S.; Dianez, M.J.; Estrada, M.D.; Lopez-Castro, A.; Perez, S. Synthesis and cristal structure of methyl 2-amino-2,6-dideoxy- $\alpha$-D-glucopiranoside-6-sulfonic acid. Carbohydr. Res. 1993, 248, 1-14. [CrossRef]

30. Chen, J.; Profit, A.A.; Prestwich, G.D. Synthesis of Photoactivatable 1,2-O-Diacyl-sn-glycerol Derivatives of 1-L-Phosphatidyl-D-myo-inositol 4,5-Bisphosphate (PtdInsP2) and 3,4,5-Trisphosphate (PtdInsP3). J. Org. Chem. 1996, 61, 6305-6312. [CrossRef] [PubMed]

31. Dosuna-Rodríguez, I.D.; Gaigneaux, E.M. Glycerol acetylation catalysed by ion exchange resins. Catal. Today 2012, 195, 14-21. [CrossRef]

32. Pruvost, R.; Boulanger, J.; Léger, B.; Ponchel, A.; Monflier, E.; Ibert, M.; Mortreux, A.; Sauthie, M. Biphasic Palladium-Catalyzed Hydroesterification in aPolyol Phase: Selective Synthesis of Derived Monoesters. ChemSusChem 2015, 8, 2133-2137. [CrossRef] [PubMed]

(C) 2017 by the authors. Licensee MDPI, Basel, Switzerland. This article is an open access article distributed under the terms and conditions of the Creative Commons Attribution (CC BY) license (http://creativecommons.org/licenses/by/4.0/). 